\title{
PENGARUH DESKRIPSI KERJA TERHADAP KINERJA PEGAWAI PADA DINAS PEKERJAAN UMUM DAN PERUMAHAN RAKYAT KABUPATEN LAMPUNG BARAT
}

\author{
Yudi Peryanto ${ }^{(1)}$, Kuswarak ${ }^{(2)}$, Maria Elina ${ }^{(3)}$ \\ Fakultas Ekonomi Universitas Sang Bumi Ruwa Jurai \\ yudi_peryanto@gmail.com,kuswarak@fe.saburai.ac.id,maria.elina@fe.saburai.ac.id
}

\begin{abstract}
Abstrak. Sebuah organisasi harus mampu mengoptimalkan kemampuan sumber daya manusia yang dimilikinya agar pencapaian sasaran dapat terlaksana, namun hal tersebut tidaklah sederhana perlu pemahaman yang baik tentang organisasi, perlu ada strategi pengembangan yang matang agar SDM yang dimiliki sebuah organisasi terpakai sesuai kebutuhan. Tujuan penelitian ini adalah untuk mengetahui pengaruh antara Deskripsi kerja terhadap Kinerja Pegawai pada Dinas Pekerjaan Umum dan Perumahan Rakyat Kabupaten Lampung Barat. Pengumpulan data penelitian menggunakan teknik sampel penelitian dari 75 responden. Metode penelitian yang digunakan adalah analisis kualitatif dan analisis kuantitatif yaitu regresi linier sederhana. Deskripsi kerja $(\mathrm{X})$ secara parsial berpengaruh positif dan signifikan terhadap kinerja pegawai $(\mathrm{Y})$. Hal ini dibuktikan dengan nilai thitung $=6,479(\mathrm{X})$ yang lebih besar dari nilai tabel $=1,670$, serta nilai signifikansi P (Sig) 0,000 lebih kecil dari $\alpha=0,05$, sehingga hipotesis Ho ditolak dan $\mathrm{H}_{1}$ "diterima", maka hipotesis yang diajukan yaitu terdapat pengaruh positif dan signifikan antara deskripsi kerja (X) terhadap kinerja pegawai (Y) pada Dinas Pekerjaan Umum dan Perumahan Rakyat Kabupaten Lampung Barat dapat diterima.
\end{abstract}

Kata kunci: Deskripsi kerja, Kinerja, Optimal, Pegawai.

\section{PENDAHULUAN}

Sebuah organisasi harus mampu mengoptimalkan kemampuan sumber daya manusia yang dimilikinya agar pencapaian sasaran dapat terlaksana, namun hal tersebut tidaklah sederhana perlu pemahaman yang baik tentang organisasi, perlu ada strategi pengembangan yang matang agar SDM yang dimiliki sebuah organisasi terpakai sesuai kebutuhan. Pada sisi inilah prestasi individu menjadi jaminan bagi organisasi bahwa organisasi akan tetap mampu menjawab setiap tantangan perubahan dan bahkan menjangkau setiap kemungkinan perubahaan pada masa yang akan datang. Dengan perkataan lain prestasi individu sangat bergantung pada prestasi masing-masing anggota organisasi.

Siagian (2010) menjelaskan bahwa bagi organisasi sendiri dalam usaha mencapai tujuan sangat membutuhkan peran serta manusia yang menjadi anggota organisasi itu. Kegiatan organisasi tidak akan berjalan tanpa adanya keterlibatan unsur manusia yang ada didalamnya. Sejalan dengan pentingnya sumber daya manusia dalam organisasi, bahwa manusia merupakan unsur yang paling penting menentukan keberhasilan atau kegagalan suatu organisasi dalam menyelenggarakan berbagai kegiatannya dan dalam rangka pencapaian tujuan dan sasaran instansi/organisasi.

Dinas Pekerjaan Umum dan Perumahan Rakyat Kabupaten Lampung Barat adalah instansi yang bertugas melayani masyarakat dalam bidang pekerjaan umum. Upaya Dinas Pekerjaan Umum Dan Perumahan Rakyat Kabupaten Lampung Barat untuk meningkatkan kualitas kelembagaan antara lain dengan berdasarkan visi, misi, tujuan, dan sasaran yang telah ditetapkan, serta mengacu pada strategi pembangunan nasional, maka Dinas Pekerjaan Umum Dan Perumahan Rakyat 
Kabupaten Lampung Barat menetapkan strategi-strategi yang merupakan serangkaian aktivitas utama untuk mencapai sasaran sasaran proses.

Dinas Pekerjaan Umum Dan Perumahan Rakyat Kabupaten Lampung Barat merumuskan beberapa strategi pembangunan dan kerangka kerja melalui serangkaian aktivitas utama untuk mencapai sasaran yang telah ditetapkan. Namun untuk melaksanakan strategi strategi tersebut dihambat oleh kemampuan yang dimiliki oleh pegawai Dinas Pekerjaan Umum Dan Perumahan Rakyat Kabupaten Lampung Barat serta pemahaman pegawai tersebut tentang deskripsi kerja yang dimilikinya.

Nitisemito (2012) memberikan definisi atau pengertian deskripsi pekerjaan (job description) sebagai penjelasan tentang suatu jabatan, tugas-tugasnya, tanggung jawabnya, wewenangnya dan sebagainya. Sedangkan kemampuan individu dapat dibagi kedalam dua bagian yaitu kemampuan nyata (actual ability) dan kemampuan potensial (potential ability). Kemampuan nyata (actual ability) yaitu kemampuan yang diperoleh melalui belajar (achivement atau prestasi), yang dapat segera didemonstrasikan dan diuji sekarang.

Kemudian pemahaman tentang kinerja dijelaskan oleh wahjosumidjo (2011) mengatakan bahwa kinerja adalah prestasi atau hasil kerja yang disumbangakan oleh seseorang atau kelompok dalam menunjang tercapainya suatu tujuan. Dengan kata lain, kinerja anggota dalam suatu organisasi baik secara individu maupun kelompok memberikan kontribusi dalam mencapai tujuan suatu organisasi.

Permasalahan yang terlihat di Dinas Pekerjaan Umum dan Perumahan Rakyat Kabupaten Lampung Barat antara lain terdapat pegawai yang tidak menguasai deskripsi kerja yang dimilikinya sehingga sering melaksanakan pekerjaan yang bukan bagiannya ataupun tidak melaksanakan tugas yang dibebankan kepadanya.

Permasalahan lainnya terdapat pegawai yang tidak menguasai tugas yang diberikan dikarenakan kemampuan individu yang ada terbatas. Permasalahan tentang kinerja antara lain target kerja yang tidak tercapai atau terlambat penyelesaiannya. Berdasarkan uraian diatas maka penulis bermaksud meneliti dengan judul: "Pengaruh Deskripsi kerja Terhadap Kinerja Pada Pegawai Dinas Pekerjaan Umum dan Perumahan Rakyat Kabupaten Lampung Barat".

\section{KAJIAN TEORI}

\section{Deskripsi Kerja}

Deskripsi pekerjaan atau job description, didefinisikan atau pengertian deskripsi pekerjaan (job description) menurut para ahli atau pakar, antara lain (1) Werther dan Davis (2017) memberikan definisi atau pengertian deskripsi pekerjaan (job description) dengan mengatakan sebagai berikut :" A written statement that explain the duties, working condition and other aspects of a specified job" , atau dalam terjemahan bebasnya dikatakan bahwa deskripsi pekerjaan (job description) adalah penyataan tertulis yang menjelaskan tugas-tugas, kondisi kerja dan aspek-aspek lainnya dari suatu jabatan tertentu. Nitisemito (2012) memberikan definisi atau pengertian deskripsi pekerjaan (job description) sebagai penjelasan tentang suatu jabatan, tugas-tugasnya, tanggung jawabnya, wewenangnya dan sebagainya.

Unit atau bagian SDM di dalam suatu perusahaan bertujuan untuk melakukan pengelolaan pegawai organisasi, mulai dari memberikan keterampilan, pelatihan, dan pengembangan kepada pegawai untuk meningkatkan kinerja mereka dalam mencapai tujuan bisnis perusahaan. Cakupan pekerjaan unit sumber 
daya manusia dari perekrutan pegawai hingga pemutusan hubungan kerja pegawai. Tugas dan Tanggung Jawab:

a. Merencanakan dan mengelola rekrutmen dan seleksi pegawai

b. Merencanakan dan melakukan orientasi pegawai baru

c. Mengidentifikasi dan mengelola kebutuhan pelatihan dan pengembangan bagi pegawai

d. Mengembangkan dan melaksanakan kebijakan dan prosedur sumber daya manusia

e. Mengelola kebijakan dan prosedur SDM

f. Mengelola kompensasi dan tunjangan pegawai

g. Memastikan kompensasi dan tunjangan sesuai dengan kebijakan perusahaan dan undang-undang

h. Mendukung tinjauan gaji tahunan

i. Melaksanakan dan memantau kinerja sistem manajemen

j. Menangani keluhan dan perselisihan pegawai

k. Mengelola proses disiplin pegawai

1. Meninjau dan memperbarui peraturan bagi pegawai

m. Menjaga sistem informasi sumber daya manusia dan database pegawai

n. Mengkoordinasikan keselamatan, kesejahteraan, dan kesehatan pegawai

o. Mempertahankan pengetahuan tentang persyaratan hukum dan peraturan pelaporan pemerintah yang mempengaruhi fungsi SDM.

\section{Pengertian Kinerja}

Kinerja adalah apa yang dilakukan dan tidak dilakukan karyawan yang mempengaruhi seberapa banyak mereka memberi kontribusi kepada organisasi yang antara lain termasuk kuantitas output, kualitas output, jangka waktu output, kehadiran di tempat kerja dan sikap kerja (Kartajaya, 2015).
Konsep ini merupakan variable dependen atau tidak bebas dan merupakan tujuan dari apa yang diharapkan dan beberapa teori pendukung digunakan untuk memperkuat hubungan dan kebijakan.

As'ad (2014) dalam bukunya Psikologi Industri mengutip pengertian kepuasan kerja menurut Blum, Wexley dan Yukl serta Tiffin. Blum (2012) mengemukakan bahwa kepuasan kerja merupakan sikap umum yang merupakan hasil dari beberapa sikap khusus terhadap faktor-faktor pekerjaan, penyesuain diri dan hubungan sosial individual di luar kerja.

Wexley dan Yukl (2012) mengemukakan bahwa kepuasan kerja adalah perasaan karyawan terhadap pekerjaannya. Tiffin pada tahun 1958 berpendapat bahwa kepuasan kerja berhubungan erat dengan sikap karyawan terhadap pekerjaannya sendiri, situasi kerja, kerjasama antar pimpinan dengan sesama karyawan.

Locke (Muchinsky, mendefinisikan kepuasan kerja sebagai suatu keadaan menyenangkan atau posistif yang berasal dari pengalaman kerja seseorang dari pekerjaannya. Kepuasan kerja dilihat dari hasil interaksi manusia dengan lingkungan kerja. Sedangkan Greenberg dan Baron (2012) menyatakan bahwa kepuasan kerja adalah reaksi kognitif, afektif, dan penilaian orang terhadap pekerjaannya. Ada beberapa faktor-faktor yang mempengaruhi kepuasan kerja yaitu faktor finansial, fisik, sosial, dan psikologis (As'ad, 2014).

Bernardin dan Russel (dalam Ruky, 2012) memberikan pengertian atau kinerja sebagai berikut: "performance is defined as the record of outcomes produced on a specified job function or activity during time period. Prestasi atau kinerja adalah catatan tentang hasil-hasil yang diperoleh dari fungsi-fungsi pekerjaan tertentu atau kegiatan selama kurun waktu tertentu. 
Pengertian kinerja lainnya dikemukakan oleh Payaman Simanjuntak (2015) yang mengemukakan kinerja adalah tingkat pencapaian hasil atas pelaksanaan tugas tertentu. Kinerja perusahaan adalah tingkat pencapaian hasil dalam rangka mewujudkan tujuan perusahaan. Manajemen kinerja adalah keseluruhan kegiatan yang dilakukan untuk meningkatkan kinerja perusahaan atau organisasi, termasuk kinerja masing-masing individu dan kelompok kerja di perusahaan tersebut.

Dessler (2017) berpendapat kinerja (prestasi kerja) pegawai adalah prestasi aktual pegawai dibandingkan dengan prestasi yang diharapkan dari pegawai. Prestasi kerja yang diharapkan adalah prestasi standar yang disusun sebagai acuan sehingga dapat melihat kinerja pegawai sesuai dengan posisinya dibandingkan dengan standar yang dibuat. Selain itu dapat juga dilihat kinerja dari pegawai tersebut terhadap pegawai lainnya.

\section{Faktor Keberhasilan Kinerja}

Menurut Bateman, Ferris dalam Timple (1992) faktor-faktor yang mempengaruhi kinerja antara lain; kemampuan, upaya, dan kesulitan tugas. Namun demikian sejumlah faktor dapat juga mempengaruhi kinerja seperti; prilaku, sikap, tindakan-tindakan rekan sekerja, bawahan atau pimpinan, kendala-kendala, sumber daya dan keadaan ekonomi. Kinerja akan sangat menentukan prestasi atau keberhasilan dalam bekerja, menurut Benge (1985) terdapat empat faktor keberhasilan dalam bekerja yaitu;

1. Karakter, kejujuran, intelektual, ketekunan, loyalitas, kepercayaan, integritas dan penerimaan tanggunga jawab.

2. Temperamen, ketenangan hati, kedewasaan emosional, penyesuaian, keseimbangan, kesabaran, dan ketenangan mental.
3. Kemampuan, fisik, intelektual, kejujuran dan sosial.

4. Perhatian, kepuasan emosional karena bekerja dengan orang lain.

\section{METODE PENELITIAN}

\section{Objek Penelitian}

Objek Penelitian dalam penelitian ini adalah pegawai Dinas Pekerjaan Umum dan Perumahan Rakyat Kabupaten Lampung Barat. Penelitian dilaksanakan pada rentang waktu Mei 2018 hingga Agustus 2018.

\section{Metode dan Teknik Pengumpulan Data}

Dalam penelitian ini jenis data yang diperlakukan adalah :

a. Data Primer

Data primer merupakan data dasar yang akan diperoleh langsung tanpa perantara orang atau lembaga lain sebagai pihak ketiga. Data primer ini diperoleh dengan wawancara melalui responden dengan menggunakan daftar pertanyaan.

\section{b. Data Sekunder}

Data skunder merupakan data yang diperoleh melalui orang lain yang berhubungan dengan permasalahan yang dipecahkan. Data sekunder ini diperoleh melalui cara studi dokumenter yaitu mengumpulkan dan mempelajari brosurbrosur serta dokumen organisasi.

Langkah-langkah pengumpulan data yang penulis lakukan dengan mengadakan penelitian lapangan yaitu Penelitian yang dilakukan padaKecamatan Balik Bukit Kabupaten Lampung Barat, adapun teknik yang digunakan dalam pengumpulan data adalah dengan :

1. Observasi, yaitu mengadakan survey atau pengamatan langsung kelokasi penelitian. 
2. Interview atau wawancara, yaitu mengadakan tanya jawab langsung dengan pegawai pada Kecamatan Balik Bukit Kabupaten Lampung Barat

3. Dokumentasi, yaitu mengumpulkan dan mencatat dokumentasi yang relevan.

4. Quisioner, yaitu membuat pertanyaan yang berhubungan dengan varibael penelitian.

\section{Sampel dan Populasi}

Menurut Suharsimi Arikunto (2012) apabila objek penelitian kurang dari 100 maka lebih baik diambil semua, selanjutnya jika jumlah lebih dari 100 maka dapat diambil antara $10-15$ persen . Diketahui jumlah pegawai berjumlah 75 orang, sehingga responden dalam penelitian ini berjumlah 75 orang. Kriteria Umum untuk skor yang dipergunakan daftar pertanyaan dalam penelitian ini adalah skala likert dengan skoring bernila 1,2,3,4,5 untuk jawaban pada setiap item pertanyaan .

\section{Metode Analisis Data}

Analisis kuantitatif yang dilakukan berdasarkan data primer yang diperoleh dari penyebaran instrument (daftar pertanyaan) kepada sampel, dan untuk mengetahui pengaruh dari variabel bebas (independent variable) terhadap variabel terikat (dependent variable).

Persamaan Regresi Linear Sederhana menentukan persamaan regresi linear sederhana untuk X :

$$
Y=a+b X+e
$$

Keterangan:

$\mathrm{Y}=$ Kinerja Pegawai

$\mathrm{a}=$ Konstanta

$\mathrm{b}=$ Koefisien regresi $\mathrm{X}$

$\mathrm{X}=$ Deskripsi kerja

e $=$ Faktor kesalahan
Untuk mengetahui besarnya pengaruh, penghitungan koefisien korelasi tersebut kemudian dilanjutkan dengan Rumus Koefisien Determinasi atau Koefisien Penentu (KP):

$$
K P=(r)^{2} x 100 \%
$$

Untuk menguji secara hipotesis secara parsial digunakan Uji t dengan rumus :

$$
t_{\text {hitung }}=\frac{r \sqrt{N-2}}{\sqrt{1-r^{2}}}
$$

Keterangan:

$$
\begin{array}{ll}
\mathrm{t}_{\text {hitung }} & =\text { Nilai } \mathrm{t} \\
\mathrm{r} & =\text { Koefisien Korelasi } \\
\mathrm{N} & =\text { Jumlah responden }
\end{array}
$$

Kriteria untuk Uji $\mathrm{t}$ adalah sebagai berikut :

a) Jika $t_{\text {hitung }}>t_{\text {tabel }}$ maka Ha diterima dan Ho ditolak.

b) Jika $\mathrm{t}_{\text {hitung }} \leq \mathrm{t}_{\text {tabel }}$ maka Ha ditolak dan Ho diterima.

\section{HASIL DAN PEMBAHASAN}

Uji validitas bertujuan menunjukkan sejauh mana suatu alat ukur dapat mengukur apa yang ingin diukur. Validitas alat pengumpul data dapat digolongkan dalam beberapa jenis, yakni validitas faktor dan butir. Uji validitas yang digunakan dalam penelitian ini adalah validitas faktr, berdasarkan tujuan untuk mengetahui sejauhmana kerangka konsep dan isi alat ukur (kuesioner) yang digunakan mampu mewakili semua aspek yang dianggap sebagai aspek kerangka konsep (Umar, 2002). Pengujian validitas dalam penelitian ini menggunakan teknik korelasi Pearsons Product Moment.

Angka korelasi yang diperoleh selanjutnya dibandingkan dengan angka kritik yang ada pada tabel nilai kritis untuk 
korelasi $\mathrm{r}$ product moment dengan derajat bebas (df) $\mathrm{N}-2$. Karena jumlah sampel $(\mathrm{N})$ uji coba dalam penelitian ini adalah 15 , maka alat ukur (kuesioner) dinyatakan valid apabila $r_{\text {hitung }}>r_{\text {tabel }}$.

\section{Uji Validitas}

Pengujian validitas faktor terhadap pertanyaan variabel $\mathrm{X}$ dan $\mathrm{Y}$ dilakukan dengan membandingkan nilai $\mathrm{r}_{\text {hitung }}$ dengan nilai $r_{\text {tabel }}$ pada tingkat kepercayaan $95 \%$. Kriteria Uji :

- Apabila $r_{\text {hitung }}>r_{\text {tabel }}$ maka pertanyaan valid dan dapat dipergunakan sebagai intrumen penelitian selanjutnya.

- Apabila $\mathrm{r}_{\text {hitung }}<\mathrm{r}_{\text {tabel }}$ tabel maka pertanyaan tidak valid dan tidak dapat dipergunakan sebagai intrumen penelitian selanjutnya.

Hasil perhitungan diatas menunjukkan nilai $\mathrm{rX}=0,956$, dan $\mathrm{rY}=0,992$. Pada tingkat kepercayaan $95 \%$ dan $\mathrm{n}=15$, diperoleh nilai $r$ tabel sebesar 0,514. Karena seluruh nilai korelasi product moment $\mathrm{rX}=0,956$ dan $\mathrm{rY}=0,992$ lebih besar dibandingkan $r_{\text {tabel }}$ 0,514, maka seluruh faktor pertnyaan valid dan dapat digunakan sebagai instrumen penelitian selanjutnya.

\section{Uji Reliabilitas}

Setelah dilakukan uji validitas, selanjutnya dilakukan uji reliabilitas. Suatu instrumen pengukuran dikatakan reliabel jika pengukurannya konsisten dan cermat akurat. Jadi uji reliabilitas instrumen dilakukan dengan tujuan untuk mengetahui konsistensi dari instrumen sebagai alat ukur, sehingga hasil suatu pengukuran dapat dipercaya.Formula yang digunakan untuk menguji reliabilitas instrumen dalam penelitian ini adalah Koefisien Alfa (á) dari Cronbach. Selanjutnya penarikan kesimpulan dengan cara membandingkan nilai $\alpha$ dengan nilai acuan sebesar 0,600. Kriterianya jika nilai hitung $\alpha$ lebih besar (<) dari 0,600, maka item instrumen dinyatakan reliabel.

\section{Analisis Kuantitatif}

Pengujian pengaruh masing-masing variabel bebas terhadap variabel terikat digunakan uji statistik $\mathrm{t}$ (t-test) dengan pengujian dua arah pada tingkat kepercayaan 95 persen $(\alpha=0,05)$ dan derajat kebebasan $\mathrm{df}=75-\mathrm{k}-1=75-2-1=72$ Hipotesis :

Ho : bi $=0=$ Deskripsi kerja $(\mathrm{X})$ secara parsial tidak berpengaruh positif dan signifikan terhadap kinerja pegawai (Y) pada Dinas Pekerjaan Umum dan Perumahan Rakyat Kabupaten Lampung Barat.

Ha $:$ bi $\neq 0=$ Deskripsi kerja (X) secara parsial berpengaruh positif dan signifikan terhadap kinerja pegawai (Y) pada Dinas Pekerjaan Umum dan Perumahan Rakyat Kabupaten Lampung Barat.

Hasil thitung variabel deskripsi kerja (X) pada Tabel Coefficients sebesar 6,947 lebih besar dari nilai $t_{\text {tabel }}$ sebesar 1,670, dan nilai signifikansi sebesar 0,000 yang lebih kecil dari 0,05 membuktikan variabel deskripsi kerja (X) secara parsial berpengaruh signifikan terhadap kinerja pegawai (Y) pada Dinas Pekerjaan Umum dan Perumahan Rakyat Kabupaten Lampung Barat. Dengan demikian disimpulkan hipotesis Ho di tolak dan $\mathrm{H}_{1}$ di terima.

Hasil perhitungan regresi diperoleh konstanta sebesar 2,605 menyatakan bahwa jika tidak ada variabel deskripsi kerja (X), maka nilai kinerja pegawai (Y) pada Dinas Pekerjaan Umum dan Perumahan Rakyat Kabupaten Lampung Barat adalah sebesar 2,605\%. Hasil perhitungan regresi linear berganda diperoleh nilai thitung untuk variabel deskripsi kerja (X) sebesar 6,479 lebih besar dari nilai $t_{\text {tabel }}$ sebesar 1,670, berarti bahwa variabel deskripsi kerja (X) 
berpengaruh positif dan signifikan terhadap kinerja pegawai $(\mathrm{Y})$ pada Dinas Pekerjaan Umum dan Perumahan Rakyat Kabupaten Lampung Barat. Besaran koefisien ( $\left.b_{1}\right)$ 0,506 yang bernilai positif menunjukkan jika variabel deskripsi kerja (X) naik sebesar $1 \%$ maka kinerja pegawai (Y) akan naik sebesar $0,506 \%$.

Dari perhitungan regresi linear berganda, diperoleh hasil yang dapat menjawab dan menerangkan hipotesis dalam penelitian ini yaitu ada pengaruh signifikan antara deskripsi kerja (X) terhadap kinerja pegawai (Y) pada Dinas Pekerjaan Umum dan Perumahan Rakyat Kabupaten Lampung Barat. Secara parsial maupun simultan kedua variabel bebas berpengaruh signifikan terhadap kinerja pegawai (Y) pada Dinas Pekerjaan Umum dan Perumahan Rakyat Kabupaten Lampung Barat. Koefisien regresi positif pada seluruh variabel menunjukkan hubungan searah, dan apabila deskripsi kerja dan kemampuan individu semakin meningkat, maka akan menimbulkan kinerja yang semakin meningkat dan baik pula.

Nilai R sebesar 0,931 menunjukkan tingkat hubungan antara variabel deskripsi kerja (X) terhadap kinerja pegawai (Y) pada Dinas Pekerjaan Umum dan Perumahan Rakyat Kabupaten Lampung Barat bersifat searah serta terkategori sangat kuat, sedangkan nilai $\mathrm{R}^{2}$ sebesar 0,866 berarti kontribusi variabel deskripsi kerja (X) mampu menjelaskan tingkat perubahan kinerja pegawai (Y) sebesar $86,6 \%$, sedangkan sisanya $13,4 \%$ dijelaskan variabel lain diluar model.

\section{KESIMPULAN DAN SARAN}

\section{Kesimpulan}

Berdasarkan hasil perhitungan dan uji hipotesis, maka disimpulkan bahwa Deskripsi kerja (X) secara parsial berpengaruh positif dan signifikan terhadap kinerja pegawai (Y). Hal ini dibuktikan dengan nilai thitung $=6,479(\mathrm{X})$ yang lebih besar dari nilai ttabel $=1,670$, serta nilai signifikansi P (Sig) 0,000 lebih kecil dari $\alpha=0,05$, sehingga hipotesis Ho ditolak dan $\mathrm{H}_{1}$ diterima. Maka hipotesis yang diajukan yaitu terdapat pengaruh positif dan signifikan antara deskripsi kerja (X) terhadap kinerja pegawai (Y) pada Dinas Pekerjaan Umum dan Perumahan Rakyat Kabupaten Lampung Barat "dapat diterima".

\section{Saran}

Adapun saran dari penelitian ini adalah sebagai berikut :

1. Dilakukannya pendalaman tentang deskripsi kerja di seksi atau bidang masing masing sehingga adanya pegawai yang tidak menguasai deskripsi dapat terhindarkan. Langkah pendalamandapat dilakukan dengan sosialisasi antar bidang, dilakukannya koordinasi antar bidang secara rutin sehingga terhindari tumpang tindih tupoksi.

2. Dilakukannya kegiatan pengembangan sumber daya manusia berupa pendidikan dan latihan serta mendorong pegawai yang ada untuk meningkatkan pendidikan dan keahliannya dengan melalui pendidikan formal, dorongan dapat dilakukan melalui beasiswa atau kerjasama antar BPS dan perguruan tinggi sehingga dengan langkah pengembangan SDM ini para pegawai dapat menguasai tugas yang diberikan dikarenakan kemampuan individu pegawai tersebut dapat berkembang.

3. Diberikannya motivasi kepada pegawai berupa penghargaan atau insentif kepada pegawai yang mampu mencapai target kerja dan tepat waktu penyelesaian, sehingga para pegawai dapat terpacu untuk mencapai target kerja yang ditugaskan kepadanya. 


\section{DAFTAR PUSTAKA}

Arikunto, Suharsimi. 2012. Prosedur Penelitian-Suatu Pendekatan Praktek. Jakarta: Penerbit Bina Aksara.

Asnawi, S. 2012. Teori Motivasi (Dalam Pendekatan Psikologi Industri dan Organisasi). Jakarta: Studia Press.

Buzzell \& Gale. 1997. Reinventing Government. How the entreperneural spirit is transforming the public sector, Addision Wesly Publising, Co. USA: Inc. Reading, MA.

Deasler, Gary. 2015. Manajemen Sumber Daya Manusia. Jakarta: PT. Ghalia Indonesia.

Edwin B. Flippo. 1996. Manajemen Personalia Jilid I. Alih bahasa oleh Moh Masud, SH.,MA. Jakarta: Erlangga.

Flippo, Edwin B. 2014. Manajemen Sumber Daya Manusia. Jakarta: Penerbit Bina Aksara.

George, D and Mallery, P. 2013. SPSS/PC Step by Step a Simple Guide and Reference. Belenot: Wods Worbb Publishing Company.

Greenberg, J and Baron, R. 2014. Behavior in Organizations. New Jersey: Prentice Hall International, Inc.

Handoko, Hani. 2015. Manajemen dan Operasi. Yogyakarta: BPFE.

Herjanto, Eddy. 2014. Manajemen Produksi dan Operasi, Edisi 2. Jakarta: Grasindo.
Mangkunegara, A.Anwar Prabu. 2015. Manajemen Sumber Daya Manusia. Bandung: Remaja Rosdakarya.

Nitisemito, Alex S. 2010. Manajemen Personalia: Manajemen Sumber Daya Manusia, Ed. 3. Jakarta: Ghalia Indonesia.

Sedarmayanti .2011. Sumber Daya Manusia dan Produktivitas Kerja. Bandung: Mandar Maju.

Siagian, Sondang P. 2017. Manajemen Sumber Daya Manusia. Jakarta: Bumi Aksara.

Sugiyono, 2008. Metode Penelitian. Bandung: Alfabeta.

Syadam, Gauzali. 2015. Manajemen Personalia Suatu Pendekatan Makro. Jakarta: Djambatan.

Veithzal Rivai \& Ahmad Fauzi .2015. Manajemen Sumber Daya Manusia. Jakarta: Raja Grafindo Persada. 